\title{
Vitamin D-3 supplementation and neurofilament light chain in multiple sclerosis
}

Citation for published version (APA):

Smolders, J., Mimpen, M., Oechtering, J., Damoiseaux, J., van den Ouweland, J., Hupperts, R., \& Kuhle, J. (2020). Vitamin D-3 supplementation and neurofilament light chain in multiple sclerosis. Acta Neurologica Scandinavica, 141(1), 77-80. https://doi.org/10.1111/ane.13185

Document status and date:

Published: 01/01/2020

DOI:

10.1111/ane.13185

Document Version:

Publisher's PDF, also known as Version of record

Document license:

Taverne

Please check the document version of this publication:

- A submitted manuscript is the version of the article upon submission and before peer-review. There can be important differences between the submitted version and the official published version of record.

People interested in the research are advised to contact the author for the final version of the publication, or visit the DOI to the publisher's website.

- The final author version and the galley proof are versions of the publication after peer review.

- The final published version features the final layout of the paper including the volume, issue and page numbers.

Link to publication

\footnotetext{
General rights rights.

- You may freely distribute the URL identifying the publication in the public portal. please follow below link for the End User Agreement:

www.umlib.nl/taverne-license

Take down policy

If you believe that this document breaches copyright please contact us at:

repository@maastrichtuniversity.nl

providing details and we will investigate your claim.
}

Copyright and moral rights for the publications made accessible in the public portal are retained by the authors and/or other copyright owners and it is a condition of accessing publications that users recognise and abide by the legal requirements associated with these

- Users may download and print one copy of any publication from the public portal for the purpose of private study or research.

- You may not further distribute the material or use it for any profit-making activity or commercial gain

If the publication is distributed under the terms of Article $25 \mathrm{fa}$ of the Dutch Copyright Act, indicated by the "Taverne" license above, 


\title{
Vitamin $D_{3}$ supplementation and neurofilament light chain in multiple sclerosis
}

\author{
Joost Smolders $^{1,2}$ (D) | Max Mimpen ${ }^{3}$ | Johanna Oechtering ${ }^{4}$ | Jan Damoiseaux ${ }^{5}$ | \\ Jody van den Ouweland ${ }^{6}$ | Raymond Hupperts ${ }^{3}$ | Jens Kuhle ${ }^{4}$
}

${ }^{1}$ Department of Neurology, Canisius Wilhelmina Ziekenhuis, Nijmegen, The Netherlands

${ }^{2}$ Neuroimmunology Research group, Netherlands Institute for Neuroscience, Amsterdam, The Netherlands

${ }^{3}$ Department of Neurology, Zuyderland Medical Center, Sittard, The Netherlands

${ }^{4}$ Department of Neurology, University Hospital Basel, Basel, Switzerland

${ }^{5}$ Central Diagnostic Laboratory, Maastricht University Medical Center, Maastricht, The Netherlands

${ }^{6}$ Department of Clinical Chemistry, Canisius Wilhelmina Ziekenhuis, Nijmegen, The Netherlands

\section{Correspondence}

Joost Smolders, ErasMS/Department of Neurology, Erasmus Medical Center, PO Box 2040, 3000CA Rotterdam, The Netherlands. Email: j.j.f.m.smolders@erasmusmc.nl

Funding information

This study was supported by grant OZ2016001 of the "Nationaal MS fonds" (The Netherlands).
Objectives: Low circulating vitamin $D$ levels are associated with an increased risk of active MRI lesions and relapses in several cohorts with relapsing remitting multiple sclerosis (RRMS). Randomized controlled supplementation trials are, however, negative on their primary endpoints, while secondary MRI endpoints suggest anti-inflammatory effects. Circulating levels of neurofilament light chain (NfL) are a biomarker of disease activity in RRMS. We explored whether 48-week high-dose vitamin $\mathrm{D}_{3}$ supplements were associated with lower circulating NfL levels.

Materials \& Methods: Of $N=40$ Dutch interferon beta-treated participants with RRMS of the SOLAR trial, plasma samples at baseline and 48-week follow-up were available. Of these participants, $\mathrm{N}=24$ were supplemented with $14000 \mathrm{IU} / \mathrm{d}$ vitamin $D_{3}$ and $N=16$ with placebo. Twenty-five hydroxyvitamin $D_{3}\left(25(\mathrm{OH}) \mathrm{D}_{3}\right)$ levels were measured with LC-MS/MS, and NfL levels were measured in duplicate with Simoa.

Results: Serum $25(\mathrm{OH}) \mathrm{D}_{3}$ levels at 48 weeks were increased in the vitamin $\mathrm{D}_{3}$ when compared to placebo group (median level 281 [IQR 205-330] vs 72 [39-88] nmol/L; $P<.01)$. NfL levels at 48 weeks did not differ between the treatment groups (median level 25.4 [IQR 19.6-32.2] vs 25.3 [17.9-30.1] $\mathrm{pg} / \mathrm{mL} ; P=.74$ ). Higher week $48 \mathrm{NfL}$ level showed a trend toward association with a higher risk of combined unique active lesions on the week $48 \mathrm{MRI}$ scan (OR 2.39 [95\% Cl 0.93-6.12] for each $10 \mathrm{pg} / \mathrm{mL}$ increase; $P=.07$ ).

Conclusions: Supplementation of high-dose vitamin $D_{3}$ for 48 weeks was not associated with lower NfL levels. This study does not support an effect of vitamin $D_{3}$ on this biomarker of neuro-axonal injury.

\section{KEYWORDS}

25-hydroxyvitamin D, multiple sclerosis, neurofilament light chain, supplementation, vitamin D

\section{1 | BACKGROUND}

Low circulating levels of 25-hydroxyvitamin D (25(OH)D) are associated with a higher risk of MRI lesions and relapses in several cohorts with relapsing remitting multiple sclerosis (RRMS). ${ }^{1}$ Randomized

Hupperts and Kuhle contributed equally. controlled trials on high-dose vitamin $D_{3}$ supplements thus far missed their primary endpoints, ${ }^{2-8}$ yet some suggested benefits on secondary MRI endpoints. ${ }^{2,7,8}$ In the SOLAR trial, we did not detect an increased proportion of interferon $\beta 1 \alpha$-treated participants with RRMS reaching no evidence of disease activity (NEDA-3) in the highdose vitamin $D_{3}$ supplements vs placebo arm, yet observed a lower number of combined unique active lesions (CUA) and a reduced T2 
volume increase on the 48-week MRI scan. ${ }^{7}$ In a sub-study among Dutch SOLAR participants (SOLARIUM), we observed no effect of vitamin $D_{3}$ supplements on general markers of lymphocyte homeostasis, ${ }^{9}$ but did observe a reduction in circulating anti-Epstein-Barr virus Nuclear Antigen-1 (Ebna-1) IgG antibodies. ${ }^{10}$ Anti-Ebna-1 IgG levels have been identified as a biomarker for disease activity of RRMS in several but not all cohorts. ${ }^{11}$ Similarly, a Norwegian trial on average-dose vitamin $D_{3}$ supplements vs placebo in RRMS did not show an effect on clinical disease parameters, ${ }^{3}$ but showed a reduction of anti-Ebna-1 IgG. ${ }^{12}$ In the latter study, blood levels of neurofilament light chain (NfL) were measured, but did not show a significant variation. ${ }^{13}$ Blood NfL levels have been identified as a biomarker of adverse disease outcomes in RRMS. ${ }^{14-16}$ To further explore a possible benefit in taking vitamin $\mathrm{D}_{3}$ supplements for people with $\mathrm{MS}$, we measured NfL levels in participants of the SOLARIUM cohort. Since serum levels of $25(\mathrm{OH}) \mathrm{D}$ were measured with a radioimmunoassay in the SOLAR trial and exceeded the detection limit of the assay, we measured in addition plasma $25(\mathrm{OH}) \mathrm{D}_{3}$ levels with liquid chromatography-mass spectrometry.

\section{2 | METHODS}

\section{1 | Study design}

Regrettably, no biomaterials were available from the SOLAR trial to study NfL levels. Therefore, the effect of vitamin $D_{3}$ supplements on blood NfL levels was explored as post hoc measurements in the Dutch SOLARIUM study, ${ }^{9,10,17}$ a sub-study of the SOLAR trial (NCT01285401). ${ }^{7}$ In short, participants were interferon $\beta 1 \alpha$-treated RRMS patients, with a first clinical event within the previous 5 years, but no relapse 30 days before inclusion. Patients were randomized to a placebo or vitamin $D_{3}$ group following procedures described elsewhere. ${ }^{7}$ Patients in the vitamin $\mathrm{D}_{3}$ group received cholecalciferol drops (Vigantol Oil, Merck) $7000 \mathrm{IU} / \mathrm{d}$ in the first 4 weeks, followed by $14000 \mathrm{IU} / \mathrm{d}$ up to week 48. As part of the SOLAR study protocol, presence of CUA at the week $48 \mathrm{MRI}$ scan (new or enlarging T2 lesions when compared to the baseline MRI scan and/or gadolinium-enhancing MRI lesions, Y/N) was registered. ${ }^{7}$ Written informed consent was acquired, and the SOLARIUM study was approved by the Ethical Committee METC-Z (Heerlen, the Netherlands).

\subsection{Vitamin D and NfL measurements}

Plasma samples were collected at baseline and week 48 and stored at $-80^{\circ} \mathrm{C}$. Plasma levels of $25(\mathrm{OH}) \mathrm{D}_{3}$ were measured using liquid chromatography-mass spectrometry/ mass spectrometry (LC-MS/ MS) following earlier published procedures. ${ }^{18,19}$ Coefficients of variation (CV) were $7.4 \%$ at $36 \mathrm{nmol} / \mathrm{L}, 4.0 \%$ at $88 \mathrm{nmol} / \mathrm{L}$, and $3.1 \%$ at $124 \mathrm{nmol} / \mathrm{L}$, respectively. Lower limit of quantification was $1 \mathrm{nmol} / \mathrm{L}$. From the SOLAR dataset, serum 25(OH)D levels were available as determined using the DiaSorin immunoassay method. ${ }^{7}$ Plasma levels
TABLE 1 Cohort characteristics

\begin{tabular}{|c|c|c|}
\hline & Placebo $(\mathrm{N}=16)$ & $\begin{array}{l}\text { Vitamin } D_{3} \\
(N=24)\end{array}$ \\
\hline Female sex (N [\%]) & $11(69)$ & $17(71)$ \\
\hline Age (y; Med [IQR]) & $40(33-47)$ & $37(31-42)$ \\
\hline $\begin{array}{l}\text { Disease duration (mo; } \\
\text { Med [IQR]) }\end{array}$ & $5.7(4.1-8.2)$ & $6.5(4.5-11.1)$ \\
\hline $\begin{array}{l}\leq 1 \text { relapse previous } \\
2 \text { y }(\mathrm{N}[\%])\end{array}$ & $2(13)$ & $9(37)$ \\
\hline $\begin{array}{l}\text { Time since last } \\
\text { relapse (mo, Med } \\
{[\text { IQR]) }}\end{array}$ & $8.0(6.6-9.3)$ & $6.5(4.0-9.9)$ \\
\hline $\mathrm{BMI} \geq 25$ (N [\%]) & $9(56)$ & $12(50)$ \\
\hline
\end{tabular}

of $\mathrm{NfL}$ were determined with a single molecule array (Simoa) analysis in duplicates following earlier published procedures. ${ }^{16}$ Median intraassay CV was $5.1 \%$ (interquartile range $3.0 \%-7.1 \%$; min-max range $1 \%-18 \%)$.

\section{3 | Statistical analysis}

Statistical analyses were conducted with GrahPad Prism (GraphPad Software) and SPSS (SPSS Inc, version 20.0). Descriptive statistics are provided for continuous variables as median and corresponding interquartile range (IQR), for proportions as number with corresponding percentage. Non-parametric paired (Wilcoxon signed ranks) or non-paired (Mann-Whitney $U$ ) statistics were applied, and correlations were tested with the Spearman correlation coefficient. Prediction of $25(\mathrm{OH}) \mathrm{D}_{3}$ levels reached in the vitamin $\mathrm{D}_{3}$ arm by $\mathrm{BMI}$ corrected for age was analyzed in a linear regression model, and prediction of week 48 CUA by NfL levels corrected for age was analyzed in a logistic regression model. A P-value $<.05$ was considered significant.

\section{3 | RESULTS}

Of the SOLARIUM sub-study, material could be retrieved of $N=40 / 53$ participants (75\%), of which $N=24 / 30$ (80\%) were allocated to the vitamin $D_{3}$ arm, and $N=16 / 23$ (70\%) to the placebo arm. These two groups were balanced for most variables, except a larger proportion of placebo-treated patients experiencing 2 or more relapses the previous 2 years (Table 1). The characteristics of this subgroup were not different from those of the total SOLARIUM cohort (data not shown).

Plasma $25(\mathrm{OH}) \mathrm{D}_{3}$ levels were significantly elevated in the vitamin $\mathrm{D}_{3}$ group, with a median level of $81.80 \mathrm{nmol} / \mathrm{L}$ (IQR 58.56123.17) at baseline and $281 \mathrm{nmol} / \mathrm{L}$ (IQR 205.29-330.40) at week $48(P<.01)$. The serum levels in the placebo group remained stable, $76.7 \mathrm{nmol} / \mathrm{L}$ (IQR 53.58-91.42) vs $71.9 \mathrm{nmol} / \mathrm{L}$ (38.95-87.87), respectively $(P=.42)$. Plasma $25(\mathrm{OH}) \mathrm{D}_{3}$ levels as measured with LC-MS/ 
MS were overall higher than serum 25(OH)D levels reported with the radioimmunoassay (median $91.55 \mathrm{nmol} / \mathrm{L}$ [IQR 62.5-161.78] vs $70 \mathrm{nmol} / \mathrm{L}$ [IQR 46-119.75], resp., $P<.01$ ), but showed a strong positive correlation within the measurable range $(<250 \mathrm{nmol} / \mathrm{L} ; R=.917$, $P<.01)$. Participants in the vitamin $D_{3}$ arm with a higher $B M I$ had numerically lower $25(\mathrm{OH}) \mathrm{D}_{3}$ levels, BMI < 25 median $304.1 \mathrm{nmol} / \mathrm{L}$ (IQR 276.61-334.33) vs BMI $\geq 25$ median 237.9 nmol/L (IQR 158.62287.42; $P=.143)$. In these participants, $25(\mathrm{OH}) \mathrm{D}_{3}$ levels reached were best predicted in a linear model (overall model fit $R^{2}=.330$; $\mathrm{P}=.02)$ containing $\mathrm{BMI}$ category $(\beta-96.37[95 \% \mathrm{Cl}-162.73$ to -30.00]; $P<.01)$ and age $(\beta 4.54$ [95\% Cl -0.431 to 9.503]; $P=.07)$.

Average plasma NfL levels were at baseline and week 48 equally low in placebo (median level $32.8 \mathrm{pg} / \mathrm{mL}$ [IQR 24.58-34.4] vs $25.3 \mathrm{pg} / \mathrm{mL}$ [IQR 17.85-30.05], resp.) and vitamin $\mathrm{D}_{3}$ arm (median levels $23.7 \mathrm{pg} / \mathrm{mL}$ [IQR 19.8-33.65] vs $25.35 \mathrm{pg} / \mathrm{mL}$ [19.55-32.13], resp.) without any significant or relevant differences between timepoints or treatment arms (Figure 1A). Baseline NfL levels correlated positively with age (Spearman $R .356 ; P=.03$ ), but not with other baseline variables. Participants with CUA $(n=8)$ on their 48 -week MRI scan had numerically slightly higher week $48 \mathrm{NfL}$ levels when compared to participants without CUA ( $n=29$, median 28.2 [IQR 22.7-38.4] vs 22.6 [18.3-28], resp., $P=.12$ ) (Figure 1B). Corrected for age, higher NfL levels corresponded with a trend toward an increased risk of CUA (OR 2.39 [95\% Cl 0.93-6.12] for each $10 \mathrm{pg}$ / $\mathrm{mL}$ increase; $P=.07$ ). Of the eight participants with CUA, six participants had $N=1$ new T2 lesion on their 48-week MRI scan, one participant had $\mathrm{N}=2$ new T2 lesions ( $\mathrm{NfL}$ level $26.5 \mathrm{pg} / \mathrm{mL}$ ), and one participant had $\mathrm{N}=3$ new T2 lesions ( $\mathrm{NfL}$ level $40.8 \mathrm{pg} / \mathrm{mL}$ ). No participants had gadolinium-enhancing MRI lesions on the week 48 MRI scan

\section{4 | DISCUSSION}

High-dosed vitamin $D_{3}$ supplements in interferon beta 1a-treated RRMS did not result in lower plasma NfL levels. This adds to the negative findings of this intervention on clinical endpoints in this study. ${ }^{7}$ It is also in line with another study, where moderate doses of vitamin $D_{3}$ supplements did not affect both clinical and $\mathrm{NfL}$ endpoints. $^{3,13}$ These negative results are paralleled by a positive effect of supplements on MRI endpoints. ${ }^{2,7}$ Therefore, despite these data, vitamin $D_{3}$ supplementation in RRMS remains a controversial issue.

Median blood NfL levels in our sample were in the same range as reported for instance in the FREEDOMS $(27.1 \mathrm{pg} / \mathrm{mL})$ and TRANSFORMS $(24.1 \mathrm{pg} / \mathrm{mL})$ studies by the same laboratory. ${ }^{16}$ However, our data set showed only two samples with $\mathrm{NfL}$ levels exceeding $60 \mathrm{pg} / \mathrm{mL}$ (baseline 86.3 and $64.3 \mathrm{pg} / \mathrm{mL}, 2.53$ and 3.42 months, respectively, after a clinical attack), where the range of $\mathrm{NfL}$ levels in these previous studies was up to $372.7-589.5 \mathrm{pg} /$ $\mathrm{mL} .{ }^{16}$ These data support the general notion of inclusion of patients without severe inflammatory activity in the SOLAR trial, which may be attributable to the introduction of many new disease-modifying therapies at the time of the SOLAR study. ${ }^{7}$ Treatment with interferon $\beta 1 \alpha$ did result in a drop of circulating $\mathrm{NfL}$ in an earlier study. ${ }^{20}$ Since the association between MRI activity and $25(\mathrm{OH})$ $D$ levels was also abrogated by treatment with interferon $\beta$ in this same cohort, ${ }^{21}$ an effect of vitamin $\mathrm{D}_{3}$ supplements on plasma $\mathrm{NfL}$ levels may be masked by this treatment. However, the trend toward an association with the presence of combined unique active lesions on week $48 \mathrm{MRI}$ suggests that $\mathrm{NfL}$ may also reflect relevant inflammatory disease activity in these low ranges. There are some limitations of the data presented. A relevant effect of vitamin $D_{3}$ supplements on blood NfL levels in cohorts with a more pronounced disease activity cannot be excluded. Most importantly, the small sample size and exploratory nature of analyses performed carry a high risk of false-negative results. Regrettably, no biomaterials of the parental SOLAR trial are available for analysis. The samples of the SOLARIUM cohort were therefore the best to explore any effect of high-dosed vitamin $D_{3}$ supplements in the context of this trial. The Dutch MS cohort is likely to show a small seasonal fluctuation of $25(\mathrm{OH}) \mathrm{D}_{3}$ levels. ${ }^{22}$ This fluctuation was not taken into account in this study, but is unlikely to have substantially confounded the large variation in $25(\mathrm{OH}) \mathrm{D}_{3}$ levels induced by highly dosed vitamin $\mathrm{D}_{3}$ supplements. The strengths of our data include the double-blind, placebo-controlled, and randomized design, and the extensive monitoring of participants during follow-up in a clinical trial.

Ongoing studies on vitamin $\mathrm{D}_{3}$ supplements in early $\mathrm{MS}$ and clinically isolated syndrome $(\mathrm{CIS})^{1}$ may be able to retrieve samples from a larger cohort of participants with more active disease for $\mathrm{NfL}$
FIGURE 1 Plasma NfL levels. A, NfL levels stratified for treatment arm and timepoint. Plac, placebo arm; Vit $D_{3}$, Vitamin $D_{3}$ arm. Difference between treatment arms was tested with the Mann-Whitney $U$ test. B, Week 48 $\mathrm{NfL}$ levels stratified for presence of combined unique active lesions (NO/YES). Significance was tested with the MannWhitney $U$ test
(A)

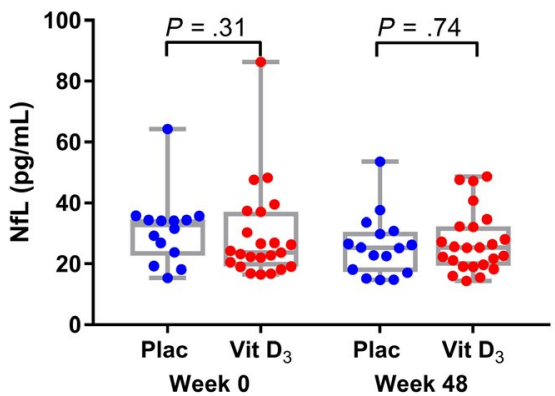

(B)

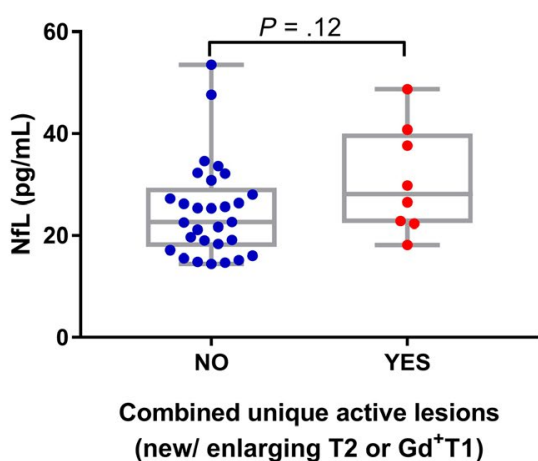


measurement. Biomarkers as NfL and MRI are important to reveal biologically relevant effects of vitamin $D_{3}$ supplements. These may be insufficiently captured in clinical endpoints in relatively small trial cohorts. Upcoming randomized controlled trials and subsequent meta-analyses of published trials may bring an end to the controversy surrounding vitamin $D_{3}$ supplementation in $M S$.

\section{ACKNOWLEDGMENTS}

We thank Dr Anne-Hilde Muris and Dr Linda Rolf for the coordination of the SOLARIUM study, as well as the participants and neurologists and MS nurses of the participating centers.

\section{CONFLICT OF INTEREST}

JS received consultancy and/or lecture of Novartis, Sanofi-Genzyme, Merck, and Biogen; MM, JO, JD, and JvdO had no conflicts of interest to declare; $\mathrm{RH}$ received fees for advisory boards and lectures and institutional research grants from Sanofi-Genzyme, Merck and Biogen; and JK received travel support, research support, speaker fees, and/or served on advisory boards by ECTRIMS, Swiss MS Society, Swiss National Research Foundation (320030_160221), University of Basel, Teva, Roche, Protagen AG, Novartis, Merck, Genzyme, Biogen, and Bayer.

\section{ORCID}

Joost Smolders iD https://orcid.org/0000-0001-9766-8661

\section{DATA AVAILABILITY STATEMENT}

The data that support the findings of this study are available from the corresponding author upon reasonable request.

\section{REFERENCES}

1. Amato MP, Derfuss T, Hemmer B, et al. Environmental modifiable risk factors for multiple sclerosis: report from the 2016 ECTRIMS focused workshop. Mult Scler J. 2017;24(5):590-603.

2. Soilu-Hänninen $M$, Aivo J, Lindström B-M, et al. A randomised, double blind, placebo controlled trial with vitamin D3 as an add on treatment to interferon $\beta-1 \mathrm{~b}$ in patients with multiple sclerosis. J Neurol Neurosurg Psychiatry. 2012;83(5):565-571.

3. Kampman MT, Steffensen LH, Mellgren SI, Jørgensen L. Effect of vitamin $D_{3}$ supplementation on relapses, disease progression, and measures of function in persons with multiple sclerosis: exploratory outcomes from a double-blind randomised controlled trial. Mult Scler J. 2012;18(8):1144-1151.

4. Stein MS, Liu Y, Gray OM, et al. A randomized trial of high-dose vitamin D2 in relapsing-remitting multiple sclerosis. Neurology. 2011;77(17):1611-1618.

5. Golan D, Halhal B, Glass-Marmor L, et al. Vitamin D supplementation for patients with multiple sclerosis treated with interferon-beta: a randomized controlled trial assessing the effect on flu-like symptoms and immunomodulatory properties. BMC Neurol. 2013;13(1):60.

6. O'Connell K, Sulaimani J, Basdeo SA, et al. Effects of vitamin $D_{3}$ in clinically isolated syndrome and healthy control participants: a double-blind randomised controlled trial. Mult Scler J Exp TransI Clin. 2017;3(3):205521731772729.

7. Hupperts R, Smolders J, Vieth R, et al. Randomized trial of daily high-dose vitamin $D_{3}$ in patients with RRMS receiving subcutaneous interferon $\beta$-1a. Neurology. 2019;93:1-19.
8. Camu W, Lehert P, Pierrot Deseilligny C, et al. Cholecalciferol in relapsing-remitting MS. A randomized clinical trial (CHOLINE). Neurol Neuroimmunol Neuroinflamm. 2019;6(5):e597.

9. Muris $A-H$, Smolders J, Rolf $L$, Thewissen $M$, Hupperts $R$, Damoiseaux J. Immune regulatory effects of high-dose vitamin $D_{3}$ supplementation in a randomized controlled trial in relapsing remitting multiple sclerosis patients receiving IFN $\beta$; the SOLARIUM study. J Neuroimmunol. 2016;300:47-56.

10. Rolf $\mathrm{L}$, Muris $A-H$, Mathias $A$, et al. Exploring the effect of vitamin $D_{3}$ supplementation on the anti-EBV antibody response in relapsing-remitting multiple sclerosis. Mult Scler J. 2017;24:1280-1287.

11. Kvistad S, Myhr K-M, Holmøy T, et al. Antibodies to Epstein-Barr virus and MRI disease activity in multiple sclerosis. Mult Scler J. 2014;20(14):1833-1840.

12. Røsjø $\mathrm{E}$, Lossius $\mathrm{A}$, Abdelmagid N, et al. Effect of high-dose vitamin D3 supplementation on antibody responses against EpsteinBarr virus in relapsing-remitting multiple sclerosis. Mult Scler. 2017;23(3):395-402.

13. Holmøy T, Røsjø E, Zetterberg H, et al. Vitamin D supplementation and neurofilament light chain in multiple sclerosis. Acta Neurol Scand. 2018;139:172-176.

14. Khalil M, Teunissen CE, Otto M, et al. Neurofilaments as biomarkers in neurological disorders. Nat Rev Neurol. 2018;14(10):577-589.

15. Barro C, Benkert P, Disanto G, et al. Serum neurofilament as a predictor of disease worsening and brain and spinal cord atrophy in multiple sclerosis. Brain. 2018;141(8):2382-2391.

16. Kuhle J, Kropshofer $\mathrm{H}$, Haering DA, et al. Blood neurofilament light chain as a biomarker of MS disease activity and treatment response. Neurology. 2019;92(10):e1007-e1015.

17. Rolf L, Muris A-H, Theunissen R, Hupperts R, Damoiseaux J, Smolders J. Vitamin $D_{3}$ supplementation and the IL-2/IL-2R pathway in multiple sclerosis: attenuation of progressive disturbances? J Neuroimmunol. 2017;314:50-57.

18. van den Ouweland JMW, Beijers AM, van Daal H. Overestimation of 25-hydroxyvitamin D3 by increased ionisation efficiency of 3-epi-25-hydroxyvitamin D3 in LC-MS/MS methods not separating both metabolites as determined by an LC-MS/MS method for separate quantification of 25-hydroxyvitamin D3, 3-epi-25-hydroxyvitamin D3 and 25-hydroxyvitamin D2 in human serum. J Chromatogr B. 2014;967:195-202.

19. Rolf L, Smolders J, van den Ouweland J, Hupperts R, Damoiseaux J. Correlation of different cellular assays to analyze T cell-related cytokine profiles in vitamin D3-supplemented patients with multiple sclerosis. Mol Immunol. 2019;105:198-204.

20. Varhaug KN, Barro C, Bjørnevik $\mathrm{K}$, et al. Neurofilament light chain predicts disease activity in relapsing-remitting MS. Neurol Neuroimmunol Neuroinflammation. 2018;5(1):e422.

21. Loken-Amsrud KI, Holmoy T, Bakke SJ, et al. Vitamin D and disease activity in multiple sclerosis before and during interferon- treatment. Neurology. 2012;79(3):267-273.

22. Muris A-H, Smolders J, Rolf L, et al. Vitamin D status does not affect disability progression of patients with multiple sclerosis over three year follow-up. PLoS ONE. 2016;11(6):e0156122.

How to cite this article: Smolders J, Mimpen M, Oechtering J, et al. Vitamin $D_{3}$ supplementation and neurofilament light chain in multiple sclerosis. Acta Neurol Scand. 2020;141:7780. https://doi.org/10.1111/ane.13185 